\title{
Struktura zatrudnienia a ekonomia w robotyzacji procesów spawalniczych
}

\author{
The structure of employment versus economy \\ in robotic welding processes
}

\section{Streszczenie}

Ciągły rozwój robotyzacji procesów produkcyjnych dyktuje niższe ceny rynkowe konstrukcji i wyrobów spawanych. Wdrożenie robotów spawalniczych w danym przedsiębiorstwie wiąże się z szeregiem zmian organizacyjnych także w strukturze zatrudnienia. Przedstawiono wpływ robotyzacji na zatrudnienie, kwalifikacje personelu oraz bezpieczeństwo i higienę pracy. Pokazano również możliwości pozyskiwania środków m.in. z funduszy unijnych na inwestycje w roboty i automaty przemysłowe.

Słowa kluczowe: fundusze z UE, robotyzacja, ekonomia

\section{Abstract}

Constant development of robotic manufacturing processes dictates lower market prices of welded structures and products. Implementation of welding robots is connected with many organizational changes, also in the structure of employment. The robotics influence on employment, personnel qualifications, and occupational health and safety are shown in this article. The possibility of obtaining money, among others, from EU funds for investment in industrial robots and machines is also described in the article.

Keywords: EU funds, robotics, economy

\section{Wstęp}

Robotyzacja procesów przemysłowych wciąż się rozwija. Roboty znajdują coraz więcej zastosowań. Dyktuje to niższe ceny rynkowe konstrukcji i wyrobów spawanych. W porównaniu do innych krajów europejskich, rozwój robotyzacji w Polsce odbywa się nadal wolniej niż oczekiwano. Powodem są nie tylko wysokie koszty inwestycyjne, ale także wciąż niska świadomość społeczna z korzyści wynikających z wdrożeń tego typu. Światowy trend rozwoju technologii spawalniczych wyraźnie zmierza w kierunku mechanizacji, automatyzacji, a także robotyzacji. Jednak nadal cenne są wysokie umiejętności manualne i doświadczenie zawodowe spawaczy, potwierdzone krajowymi i międzynarodowymi certyfikatami. Nie jest zatem prawdą, że robot wykonujący zadania spawalnicze, w których zastępuje człowieka jest jego wrogiem. Wręcz przeciwnie, współczesne warunki przemysłowe narzucają ścisłą współpracę człowieka z maszyną. Należy mieć jednak świadomość, że wdrożenia robotyzacji wiążą się niejednokrotnie z koniecznością zmiany struktury zatrudnienia i oddelegowania pracowników do innych obowiązków. Jednym z głównych celów stosowania robotyzacji spawalnictwa jest wyeliminowanie człowieka z pracy w miejscach, w których warunki są niebezpieczne i zagrażają zdrowiu lub życiu spawacza. Oczywiście kolejnym ważnym aspektem pozostaje zwiększenie powtarzalności i wydajności procesów przy zachowaniu lub nawet poprawieniu jakości. Istotnym elementem na tym etapie współpracy spawacza z robotem spawalniczym jest umiejętne i racjonalne wykorzystywanie wiedzy technologicznej. Doświadczenie i wiedza spawacza pomaga w swobodnym korzystaniu z wszystkich atutów jakie daje robotyzacja spawania [1,3].

\section{Trendy rozwoju robotyzacji}

Coraz częstszym zadaniem jakie stawiane jest producentom konstrukcji spawanych jest wyższa jakość przy niskich kosztach i jak najszybszym wykonaniu danego zlecenia. Dlatego też coraz częściej producenci decydują się na wdrażanie zautomatyzowanych i zrobotyzowanych rozwiązań, opłacalnych przede wszystkim w krajach uprzemysłowionych i wysoko rozwiniętych. Z prognoz ekspertów z Międzynarodowej Federacji Robotyki (IFR) wynika, że przez najbliższe dwa lata (2015-2017) zapotrzebowanie na roboty przemysłowe osiągnie poziom 190 tysięcy sztuk. Największym wzrostem będą mogły pochwalić się kraje azjatyckie (wzrost na poziomie $21 \%$ ), a przede wszystkim Chiny, Tajwan i Korea. Wzrost $11 \%$ prognozowany jest dla Ameryki Północnej, natomiast 6\% dla Europy. W poniższej tabeli przedstawiono dane dotyczące szacowanej, rocznej sprzedaży robotów w Europie (Tablica I) $[11,15]$. W 2014 roku stan robotyzacji powinien wynieść 205000 sztuk robotów przemysłowych. Jeśli globalna sytuacja

Mgr inż. Monika Restecka - Instytut Spawalnictwa, Gliwice.

Autor korespondencyjny/Corresponding author. monika.restecka@is.gliwice.pl 
gospodarcza, uwzględniając m.in. konflikt między Ukrainą i Rosją, się poprawi wzrost ten może być jeszcze większy $[11,15]$.

$\mathrm{Na}$ podstawie raportów opracowanych przez IFR, można stwierdzić, że robotyzacja procesów przemysłowych, a w tym procesów spawalniczych jest trendem ogólnoświatowym, a co za tym idzie wyznacznikiem konkurencyjności. W latach 2015-2017 również polskie przedsiębiorstwa będą inwestować w automatyzację i robotyzację [15].

\section{Wpływ robotyzacji na strukturę zatrudnienia}

Zastosowanie robotyzacji w wybranych procesach przemysłowych $w$ danym przedsiębiorstwie wiąże się $z$ szeregiem zmian organizacyjnych $\mathrm{m}$. in. w strukturze zatrudnienia pracowników. Zastąpienie pracy ludzkiej robotami może w konsekwencji doprowadzić do redukcji niektórych etatów. Na podstawie badań przeprowadzonych przez IBnGR można stwierdzić, że najczęściej w wyniku robotyzacji, pracownicy oddelegowani zostają do innych obowiązków. Spadek zatrudnienia występuje rzadziej, co pokazuje poniższy wykres (rys. 1). 65\% firm wykazało brak zmian w zatrudnieniu, natomiast tylko ok. 20 \% spadek zatrudnienia. W związku ze wzrostem mocy produkcyjnej uzyskanej dzięki robotom w niektórych firmach pojawiła się konieczność stworzenia nowych miejsc pracy i powiększenia kadry pracowniczej. Prawie 20\% ankietowanych firm zadeklarowało taką potrzebę.

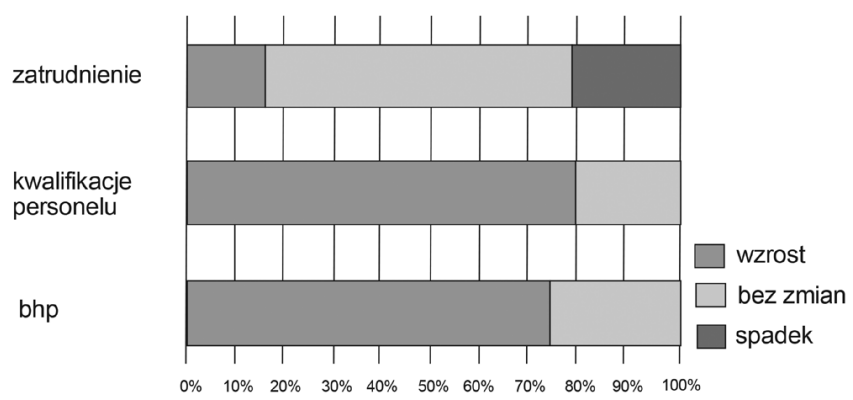

Rys. 1. Wpływ robotyzacji na zatrudnienie, kwalifikacje personelu oraz bezpieczeństwo i higienę pracy [6]

Fig. 1. Robotics influence on employment, personnel qualifications and occupational health and safety

Gedia Poland Assembly, producent części dla przemysłu motoryzacyjnego należy do grupy firm, w której powiększono zasoby ludzkie. Decyzja o robotyzacji w tym przedsiębiorstwie została podjęta z uwagi na konieczność zapewniania wysokiej jakości przy zaawansowanym technologicznie produkcie. Dodatkowo praca przy procesach spawalniczych związanych z odpowiednimi detalami była niebezpieczna, a w niektórych przypadkach wręcz niemożliwa. Obecnie w zakładzie zostało zainstalowanych 57 robotów. $60 \%$ $z$ nich to roboty przeznaczone do zgrzewania punktowego natomiast $40 \%$ to roboty spawalnicze oraz roboty zajmujące się transportowaniem detalu. Prace wykonywane przez roboty należy wykonywać w sposób ciągły i precyzyjny. Dzięki temu rozwiązaniu firma może pochwalić się prawie $100 \%$ powtarzalnością w kwestii jakości i wymiarów. Istnieje także możliwość elastycznego wprowadzania zmian do procesu na życzenie klienta, a także możliwość wykonywania różniących się od siebie detali na jednej maszynie. Moce produkcyjne wzrosły na tyle, że powstało ok. 200 nowych miejsc pracy. Bez nowych pracowników niemożliwy byłby dalszy rozwój firmy. Dzięki zwiększeniu zatrudnienia i wdrożeniom robotyzacyjnym Gedia wykonuje dużo większą ilość zleceń rocznie, a także posiada zaplecze na wykonywanie bardziej złożonych i wymagających projektów [6].

Kolejnym przykładem pozytywnego wpływu robotyzacji na zatrudnienie jest kopalnia węgla brunatnego w Koninie (PAK), która zajmuje się wydobyciem. Aby wydobywanie węgla było możliwe należy w pierwszej kolejności zdjąć nakład czyli ziemię. Do tej czynności służą koparki uzbrojone m.in. w naroża i zęby. PAK zautomatyzował stanowiska spawalnicze do wytwarzania ww. zębów. Dzięki robotyzacji obecna, roczna produkcja to ok. 25000 sztuk. Aby wyprodukować podobną ilość detalu potrzebnych było 3-4 pracowników ponieważ 1 pracownik spawał 30 sztuk dziennie. Robot potrafi spawać z prędkością ok. 70 sztuk na dzień. Po wdrożenie robotyzacji na stanowiskach pracują 2 roboty spawalnicze i wykonują tę samą pracę, ale przy obsłudze jednej osoby. Pozostałe osoby zostały oddelegowane do innych zadań $\mathrm{m}$. in. do napawania naroży. Dzięki takiej organizacji pracy produkcja została usprawniona a produktywność się zwiększyła. Robotyzacja dobrze wpłynęła także na kulturę i środowisko pracy. Stanowiska wyposażone są w wyciągi, które wychwytują dymy spawalnicze, a przy stanowiskach zrobotyzowanych pracownicy nie są bezpośrednio narażeni na działanie promieniowania ultradźwiękowego i podczerwonego [6].

\section{Roboty zastępują człowieka w niebezpiecznych warunkach}

Proces technologiczny, jakim jest spawanie, jest źródłem emisji dymów oraz toksycznych gazów. Wraz z pojawieniem się nowych metod spawania oraz nowych materiałów

Tablica I. Roczna sprzedaż robotów przemysłowych W Europie wraz z prognozami na lata 2012-2017 [11]

Table I. Annual sales of industrial robots in Europe along with forecasts for the years 2012-2017

\begin{tabular}{|c|c|c|c|c|c|c|}
\hline Kraj & 2012 & 2013 & $2014^{\star}$ & $2015^{\star}$ & $2016^{*}$ & $2017^{*}$ \\
\hline Europa & 41.218 & 43.384 & 46.000 & 47.000 & 49.000 & 55.000 \\
\hline Czechy & 1.040 & 1.337 & 1.800 & 2.000 & 2.300 & 2.600 \\
\hline Francja & 2.956 & 2.161 & 2.300 & 2.400 & 2.600 & 2.800 \\
\hline Niemcy & 17.528 & 18.297 & 19.500 & 19.500 & 20.000 & 21.000 \\
\hline Włochy & 4.402 & 4.701 & 4.800 & 5.000 & 5.200 & 5.500 \\
\hline Hiszpania & 2.005 & 2.764 & 3.000 & 3.500 & 3.600 & 3.800 \\
\hline Wielka Brytania & 2.943 & 2.486 & 2.500 & 3.000 & 3.200 & 3.500 \\
\hline inne & 10.344 & 11.538 & 12.100 & 11.600 & 12.100 & 15.800 \\
\hline Ogółem & 159.346 & 178.132 & 205.000 & 232.850 & 258.900 & 288.000 \\
\hline
\end{tabular}


dodatkowych liczba narażonych na niebezpieczne warunki spawaczy stale rośnie. Według Outlook Handbook w 2014 roku w USA liczba zatrudnionych spawaczy wynosiła 500 000, natomiast na świecie liczba ta zbliżyła się do $2 \mathrm{mln}$. Aby zmniejszyć narażenie pracowników na szkodliwe warunki stosuje się wyciągi dymów, odzież ochronną, a także w miarę możliwości steruje się parametrami procesu. Jednym z rozwiązań jest także robotyzacja. Szczególnie w przypadku spawania najbardziej szkodliwych materiałów lub spawania w zamkniętych przestrzeniach. Najbardziej niebezpieczne dla życia i zdrowia spawaczy jest spawanie stali niskostopowych w przestrzeniach zamkniętych, spawanie stali wysokostopowych, stopów aluminium, spawanie drutami proszkowymi samoosłonowymi oraz spawanie materiałów zawierających substancje rakotwórcze $[8,12]$.

Przykładem ciekawego zastosowania robotyzacji w warunkach zagrażających życiu i zdrowiu jest nowopowstały projekt robota dla przemysłu stoczniowego. Przemysł ten jest jednym z najniebezpieczniejszych środowisk dla osób zajmujących się spawaniem. Mimo to większość prac spawalniczych wykonywanych jest tutaj za pomocą ludzkich rąk. Dzieje się tak ze względu na trudny dostęp do wielu spawanych miejsc. Jest to bardzo duże wyzwanie, ponieważ istniejące warunki takie jak opary, zwarcia elektryczne oraz wysokie temperatury (ok. $40-50^{\circ} \mathrm{C}$ ) narażają zdrowie pracowników. Te warunki są jeszcze trudniejsze jeśli chodzi o wnętrze podwójnego kadłuba statku. Dwukadłubowa konstrukcja z płyt stalowych zamknięta jest ze wszystkich stron (rys. 2) Tego typu konstrukcje są wymagane przez międzynarodowe przepisy morskie dla wszystkich tankowców, aby zapobiec wyciekom ropy. Wewnątrz podwójnej burty istnieje tylko kilka miejsc łatwo dostępnych dla spawacza.

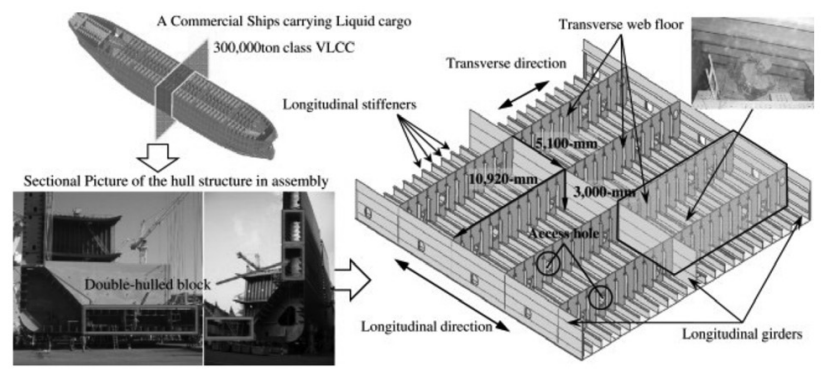

Rys. 2. Dwukadłubowa struktura tankowca w przemyśle stoczniowym [5] Fig. 2. Structure of the double hull oil tanker in in the shipbuilding industry

Do tej pory nie istniało rozwiązanie zrobotyzowane, które mogłoby wyeliminować człowieka z tego procesu. Roboty, które są stosowane w przemyśle stoczniowym na otwartych przestrzeniach (6-osiowe) nie znalazły zastosowania w tym przypadku przede wszystkim ze względy na swoje gabaryty. Często tego typu roboty instalowane są na suwnicy, która montowana jest do sufitu stoczni i nie ma dostępu do wnętrza burty. Propozycje zmechanizowania spawania podwójnego kadłuba opierały się na wózkach spawalniczych, których właściwości spawania były zadowalające, jednak przy ich użyciu nie można było wykonać złącza na kształt litery "U”. Problemem był niedobór stopni swobody, który został rozwiązany dzięki nowemu projektowi robota spawalniczego Rail Runner $X(R R X)$. Robot ten posiada 6 stopni swobody i jest osadzony na 6-osiowej, mobilnej platformie, a jego masa całkowita nie przekracza 60 kilogramów. Prototyp został wykonany przez Daewoo Shipbuilding and Marine Engineering. System i gabaryty robota pozwalają na jego pracę w wąskich i ciasnych pomieszczeniach oraz na wykonywanie złączyw oczekiwanym kształcie. Pozwoliło to na wyeliminowanie człowieka z zadań spawalniczych w trudnych warunkach wnętrza podwójnej burty tankowców $[4,5,7]$.
Znacznym źródłem emisji dymów i toksycznych gazów jest także spawanie stali nierdzewnej oraz aluminium i jego stopów. Firma Alvo Group Gastrometal producent stołów zabiegowych i operacyjnych, klatek, wanien rehabilitacyjnych oraz stołów i wanien do mycia zwierząt wykonuje spawanie materiałów z ww. niebezpiecznej dla spawacza grupy. Ponadto proces spawania wymienionych komponentów polega na wykonaniu bardzo długich spoin. Przedsiębiorstwo zdecydowało się na wdrożenie zrobotyzowanego stanowiska składającego się z robota Fanuc S-420i z kontrolerem R-J2. Instalacja pomogła zarówno $\mathrm{w}$ aspekcie technologicznym jak i w zwiększeniu produktywności. Dodatkowym, ale równie ważnym atutem jest to, że operator nie pracuje obecnie w bezpośrednim oddziaływaniu dymów spawalniczych. Wykwalifikowani spawacze wykonują bardziej specjalistyczne prace nie zagrażające ich zdrowiu [16].

Na podstawie wyżej wymienionych przykładów oraz prognoz IFR można potwierdzić, że robotyzacja to trend ogólnoświatowy. Jednak procesy spawalnicze są bardzo złożone i nadal pozostają obszary, w których, z różnych względów, nie możliwe jest zastosowanie robotów. W takich przypadkach można zastanowić się nad częściowymi, zmechanizowanymi rozwiązaniami, które mogą usprawnić produkcję i niejednokrotnie pomóc spawaczom w monotonnych, prostych zadaniach. Takimi rozwiązaniami są m.in. automaty spawalnicze tj. wózki i traktory poruszające się najczęściej z wykorzystaniem torowiska, wymuszającego kształt spoiny, słupowysięgniki ułatwiające prace spawalnicze np. przy poszyciu zbiorników, przejezdne urządzenia typu bramowego, szczególnie nadające się do spawania profili (rys. 3).

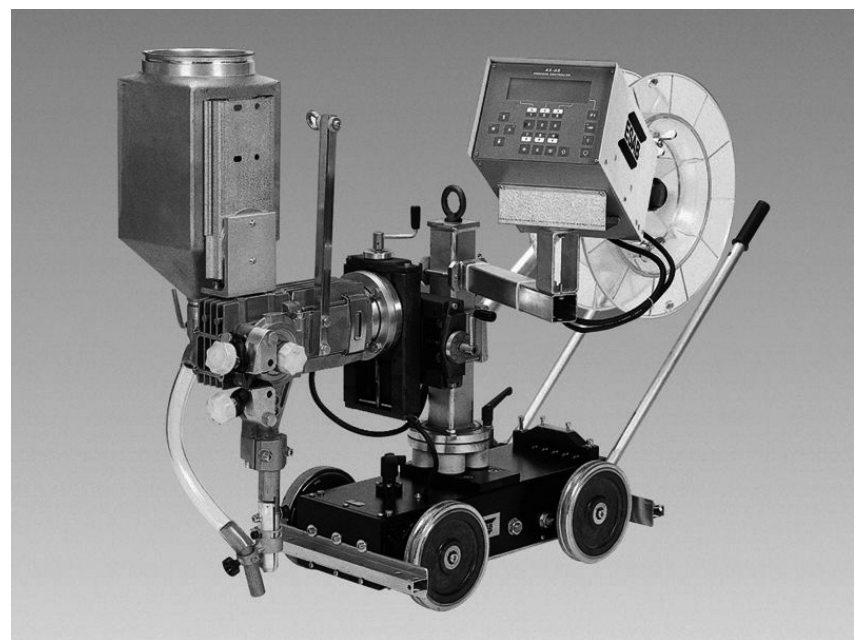

Rys. 3. Przykład traktora spawalniczego [źródło: www.rywal.com.pl] Fig. 3. Example of welding tractor [źródło: www.rywal.com.pl]

\section{Kwalifikacje spawacza a robotyzacja}

Polska może pochwalić się 4 tys. osób, które dysponują międzynarodowymi lub europejskimi dyplomami z dziedziny spawalnictwa, a ponad 8 tys. osób ma potwierdzone kwalifikacje w zakresie NDT. Z badań przeprowadzonych przez Instytut Spawalnictwa wynika, że z 200 ankietowanych firm spawalniczych każda posiada przynajmniej jednego specjalistę z międzynarodowym dyplomem (rys. 4) [9,10].

Naturalną konsekwencją uruchomienia urządzeń zaawansowanych technologicznie w danym zakładzie jest wzrost kwalifikacji kadry pracowniczej. Nabycie umiejętności codziennej obsługi robotów przemysłowych wymaga przejścia odpowiedniej serii szkoleń. Operator robotów spawalniczych powinien posiadać kwalifikacje zgodne z PN-EN 1418:2000: Personel spawalniczy - Egzaminowanie operatorów urządzeń spawalniczych oraz nastawiaczy zgrzewania oporowego dla w pełni zmechanizowanego i automatycznego spajania 
metali. Najczęściej przed kandydatami do tego typu szkoleń stawiane są wymagania: ukończenie 18 roku życia, co najmniej podstawowego lub zawodowego wykształcenia oraz zdolność do wykonywania zawodu spawacza, potwierdzona orzeczeniem lekarskim. Kursy szkoleniowe powinny być przeprowadzone zgodnie z: PN-EN 287-1 A1, PN-EN 287-2 A2, PN-EN 9606-3. Operator, który zdał egzamin państwowy potwierdzający kwalifikacje oraz posiada zaświadczenie o ukończeniu szkolenia ma możliwość zautomatyzowanego spawania metodami: 111 - spawania łukowego elektrodą otuloną, stali niestopowych; 131 (MIG) - spawania elektrodą topliwą w osłonie gazów obojętnych aluminium; 135 (MAG) - spawania elektrodą topliwą w osłonie gazów aktywnych; 136 (MAG) - spawania elektrodą topliwą w osłonie gazów aktywnych/drutem proszkowym; 141 (TIG) - spawania elektrodą nietopliwą w osłonie gazów obojętnych. Ponadto personel techniczny powinien posiadać dodatkową wiedzę dotyczącą konserwacji, napraw, instalacji elektrycznej itp. Firmy ankietowane przez IBnGR w $80 \%$ potwierdziły podwyższenie kwalifikacji swoich pracowników związanych z wdrożeniami robotyzacji. Ponieważ roboty zwykle zastępują pracowników na stanowiskach gdzie warunki pracy były dla nich szkodliwe lub w pracach szczególnie monotonnych i uciążliwych dla zdrowia, ogólny poziom bezpieczeństwa i higieny pracy również został podniesiony $[6,13]$.

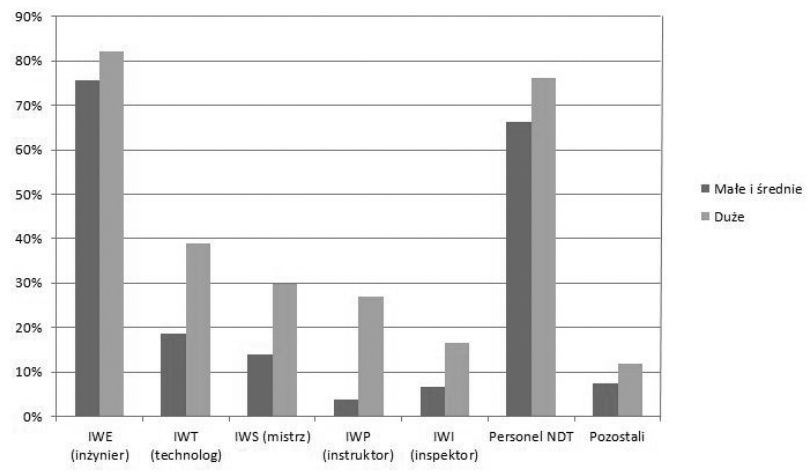

Rys. 4. Personel spawalniczy z międzynarodowymi dyplomami zatrudniony $w$ analizowanych firmach (wg \% odpowiedzi) [9]

Fig. 4. Welding personnel with international diplomas employed in the analyzed companies (response rate)

\section{Inwestycja w roboty - skąd wziąć pieniądze?}

Gdy zapada decyzja o wdrożeniu robotyzacji, powstaje pytanie skąd wziąć pieniądze na tak ogromną inwestycję. Z badań przeprowadzonych przez Instytut Spawalnictwa wynika, że ponad $50 \%$ firm nie decyduje się na wdrożenie robotów z powodu wysokich kosztów inwestycji oraz $40 \%$ z powodu braku funduszy. Niechęć do zmian i zadowolenie z istniejącego stanu występuje w $27 \%$ dużych firm oraz w $10 \%$ MSP. Małe i średnie przedsiębiorstwa w $20 \%$ przyznają także brak odpowiedniej wiedzy. Dla dużych firm nie stanowi to tak dużego problemu jednak należy mieć świadomość, że bez informacji o nowościach i korzyściach jakie niesie za sobą wdrażanie robotyzacji nie będzie znaczącego postępu w procesach produkcyjnych (rys. 5) $[9,10]$.

Jednym z rozwiązań jest skorzystanie z funduszy unijnych. Programy krajowe i regionalne zostały przewidziane na lata 2014-2020. Ministerstwo Infrastruktury i Rozwoju informuje, że fundusze europejskie z dużym naciskiem przeznaczone zostaną na działania prowadzące do wzrostu konkurencyjności i innowacyjności polskiej gospodarki. Ponad połowa środków (40,2 mld euro) zostanie przeznaczona na wsparcie m.in. badań naukowych i konkurencyjności MSP. 40\% puli przekazane zostanie na programy regionalne w różnych obszarach tematycznych. Programy te będą dwufunduszowe.
Część funduszy umożliwi sfinansowanie szkoleń, podnoszenie kwalifikacji personelu oraz outplacement, natomiast druga część przeznaczona zostanie na typowe inwestycje. Podobnie jak inne kraje Polska musiała wybrać krajowe, inteligentne specjalizacje. Wybranych zostało 18 specjalizacji w 5 działach. Jednym z działów są innowacyjne technologie i procesy przemysłowe. W ramy tej grupy tematycznej obok wielofunkcyjnych materiałów i materiałów kompozytowych o zaawansowanych właściwościach (w tym nanoprocesy i nanoprodukty), sensorów (w tym biosensory) i inteligentnych sieci sensorowych, inteligentnych sieci i technologii geoinformacyjnych, elektroniki opartej na polimerach przewodzących, optoelektronicznych systemów i materiałów, ujęto także automatyzację i robotykę procesów technologicznych [2].

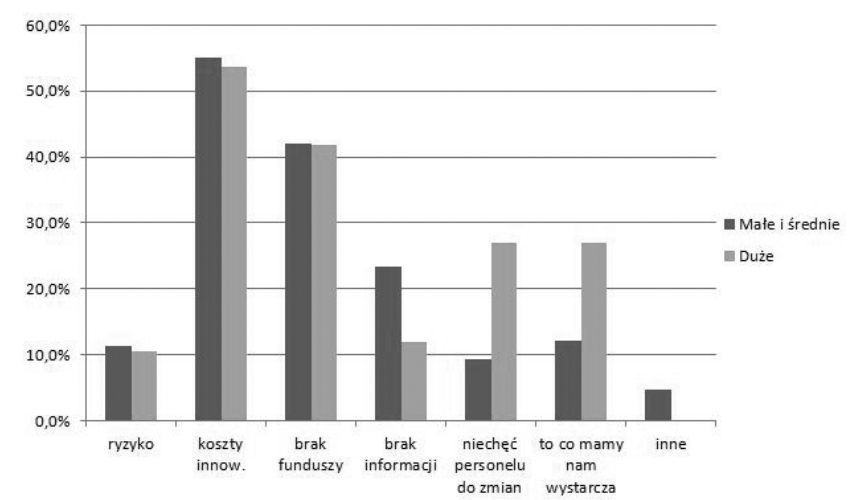

Rys. 5. Czynniki utrudniające działalność innowacyjną w spawalnictwie (\% odpowiedzi) [9]

Fig. 5. Factors hindering innovation in the welding industry (response rate)

Dodatkowym źródłem finansowania z Brukseli dla producentów zamierzających wdrożyć robotyzację jest program Horyzont 2020. Największy w historii, unijny program ramowy na rzecz badań naukowych i innowacji. Są to jednak środki przeznaczone głównie dla MSP. Jego budżet sięga blisko 80 mld euro na lata 2014-2020. Cały program podzielony jest na cztery czasowe programy pracy. Stanowi to duże ułatwienie i daje większą przewidywalność. Nowym rozwiązaniem w Horyzoncie 2020 jest Open Access czyli obowiązek publikowania wyników projektu oraz zapewnienie otwartego dostępu do publikacji naukowych. Ocena wniosków dokonywana jest na bazie 3 podstawowych kryteriów. Pierwszym z nich jest "doskonałość" czyli przełomowy charakter projektu, drugim „wpływ” czyli opis przewidywanych skutków działania np. przewidywanie zwiększenia konkurencyjności, trzecim „jakość i efektywność wdrożenia”. W ramach wsparcia wyodrębniono SME Instrument podzielony na różne obszary tematyczne. W ramach działania Instrumentu wyznaczono 3 fazy, które podlegają finansowaniu: fazę pierwszą czyli studia wykonalności (m.in. weryfikacja techniczna, praktyczna, ekonomiczna - dofinansowanie max. 50000 euro w formie ryczałtu), fazę drugą czyli działania badawcze (demonstracja, testowanie prototypów, pilotaż itp.) oraz fazę trzecią czyli wdrożenie. Faza trzecia podlega finansowaniu pośredniemu przez fundusze podwyższonego ryzyka. Poziomy gotowości dla projektu Horyzont 2020 określone zostały w General Annexes sekcji G. Na ich podstawie określone zostały progi dofinansowania:

- researches and innovation actions (RIA) - dofinansowanie

na badania i innowacje: 100\% kosztów kwalifikowanych - innovation actions (IA) - dofinansowanie na innowacje: $70 \%$

kosztów kwalifikowanych

Podstawowe dokumenty oraz procedura składania wniosków, krok po kroku, znajduje się na stronie Ministerstwa Nauki i Szkolnictwa Wyższego. Warto także monitorować 
terminy naboru do projektów związanych z działem automatyzacji i robotyki procesów technologicznych na stronie: www.funduszeeuropejskie.gov.pl w zakładce "skorzystaj" $[2,14]$.

Dodatkowymi możliwościami uzyskania finansowania na automatyzację i robotyzację procesów spawalniczych są m.in. kredyty on-line, kredyty gwarantowane dla firm, pożyczki firmowe, kredyty w rachunku bieżącym, kredyty zabezpieczone dla aktywnych przedsiębiorców, finansowanie z linią kredytową, kredyty z gwarancją BGK, finansowanie środków trwałych w postaci leasingu, długoterminowe kredyty z zabezpieczeniem w postaci hipoteki i wiele innych.

\section{Podsumowanie}

Z danych IFR wynika, że pomimo wysoko wykwalifikowanego personelu spawalniczego, Polska jest jednym z najmniej zrobotyzowanych krajów na świecie. Biorąc pod uwagę prognozy ekspertów oraz aktualne tendencje światowego rynku przemysłowego, należy oczekiwać, że zapotrzebowanie polskich przedsiębiorców na roboty przemysłowe, a w tym na roboty spawalnicze, będzie rosnąć w najbliższych latach. Wzrost ten w dużej mierze spowodowany będzie presją, jaką będzie wywierać konkurencja. Jak pokazują licznie przytoczone przykłady, zastosowanie robotów spawalniczych pozytywnie wpływa na rentowność firmy, usprawnienie produkcji, obniże-

\section{Literatura}

[1] Bielski M.: Spawacze i automaty. Przegląd Techniczny, nr 5/2014.

[2] Cieszkowska D.: Pieniądze dla firm cz. 1. Fundusze z UE 2014-2020, Dziennik Gazeta Prawna, luty 2015 r.

[3] Ebel K.H.: The impact of industrial robots on the word of work. Robotics 2013 .

[4] Lee D., Kim J.: Development of a mobile robotic system for welding in the double-hulled structure of a ship, Robotics and Computer - Integrated Manufacturing. 26 (1), kwiecień 2011/

[5] Lee D., Ku N., Kim T., Kim J., Lee K., Son Y.: Development and application of an inteligent welding robot system for shipbuilding. Robotics and Computer - Integrated Manufacturing, 27, kwiecień 2011.

[6] Łapiński K., Peterlik M., Wyżnikiewicz B.: Wpływ robotyzacji na konkurencyjność polskich przedsiębiorstw. maj 2013.

[7] Oh M., Lee S., Kim T.: Design of a teaching pendant program for a mobile shipbuilding welding robot Rusing PDA. Computer Aided Design, nr 42, marzec 2010.

[8] Popovic O., Prokic-Cvetkowic R., Burzic M., Lukic U., Beljic B.: Fume and gas emission during arc weldig. Hazard and recommendation. Renevable and Sustainable Energy Reviews, nr 37, wrzesień 2014. nie jej kosztów, a także na poprawienie jakości wyrobu. Dodatkowymi atutami jest niejednokrotne zwiększenie zatrudnienia oraz podnoszenie kwalifikacji personelu spawalniczego. Roboty wyręczają także wykwalifikowany personel w pracach związanych z trudnymi lub niebezpiecznymi dla życia lub zdrowia warunkami. Mechanizm konkurencyjny związany z dynamicznym wzrostem liczby robotów w światowym przemyśle w najbliższym czasie spowoduje, że coraz częściej polscy przedsiębiorcy będą decydować się na robotyzację produkcji, zwłaszcza że możliwości na finansowanie, tej niemałej, inwestycji jest wiele.
[9] Restecka M., Zeman W.: Innowacje - modne hasło czy konieczność? Magazyn Przemysłowy nr 11(132)/listopad 2013.

[10] Restecka M., Zeman W.: Innowacyjność producentów konstrukcji i wyrobów spawanych na przełomie lat 2012/2013 w oparciu o wyniki badań ankietowych. Praca własna, Instytut Spawalnictwa, listopad 2013.

[11] Restecka M.: Robotyzacja - trend ogólnoświatowy. Biuletyn Instytutu Spawalnictwa, nr 1/2015.

[12] Sriram K., Lin G., Jefferson A., Store S., Afshari A., Keane M., McKinney W., Jackson M., Chen B., Schnegler-Berry D., Cumpston A., Cumpston J., Roberts J., Frazer D., Antoni J.: Modifiyng welding process parameters can reduce the neurotoxic potential of manganawe - containing welding fumes. Toxicology, nr 328, luty 2015.

[13] Strona internetowa: www.bhp.abc.com.pl

[14] Strona internetowa: www.funduszeeuropejskie.gov.pl

[15] Strona internetowa: www.ifr.org

[16] Strona internetowa: www.robotyprzemyslowe.pl 